
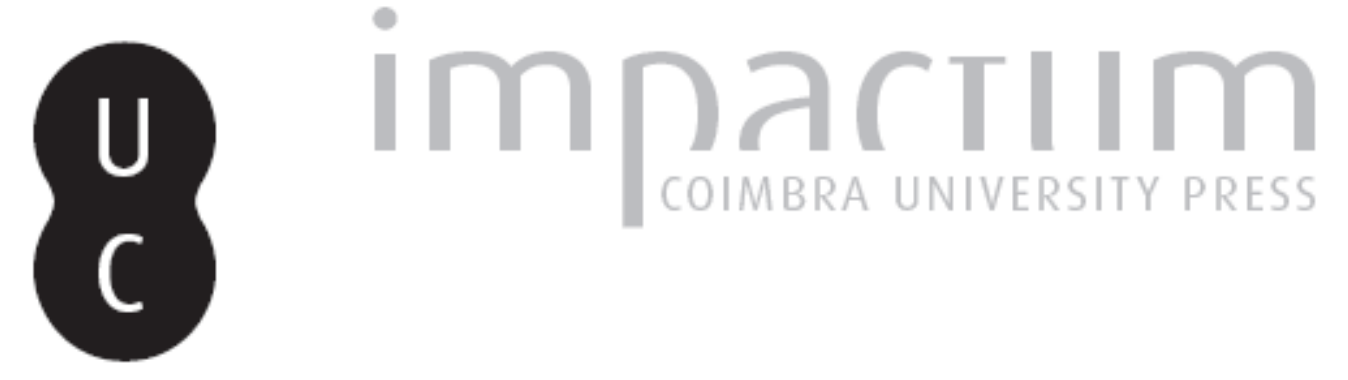

\title{
Presença italiana na tratadística portuguesa da primeira metade do século XVIII: a Nova arte de conceitos de Francisco Leitão Ferreira
}

Autor(es): $\quad$ Conrieri, Davide

Publicado por: Imprensa da Universidade de Coimbra

URL persistente:

URI:http://hdl.handle.net/10316.2/42448

DOI:

DOI:https://doi.org/10.14195/0870-8584_0_5

Accessed : $\quad$ 26-Apr-2023 11:31:17

A navegação consulta e descarregamento dos títulos inseridos nas Bibliotecas Digitais UC Digitalis, UC Pombalina e UC Impactum, pressupõem a aceitação plena e sem reservas dos Termos e Condições de Uso destas Bibliotecas Digitais, disponíveis em https://digitalis.uc.pt/pt-pt/termos.

Conforme exposto nos referidos Termos e Condições de Uso, o descarregamento de títulos de acesso restrito requer uma licença válida de autorização devendo o utilizador aceder ao(s) documento(s) a partir de um endereço de IP da instituição detentora da supramencionada licença.

Ao utilizador é apenas permitido o descarregamento para uso pessoal, pelo que o emprego do(s) título(s) descarregado(s) para outro fim, designadamente comercial, carece de autorização do respetivo autor ou editor da obra.

Na medida em que todas as obras da UC Digitalis se encontram protegidas pelo Código do Direito de Autor e Direitos Conexos e demais legislação aplicável, toda a cópia, parcial ou total, deste documento, nos casos em que é legalmente admitida, deverá conter ou fazer-se acompanhar por este aviso.

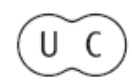




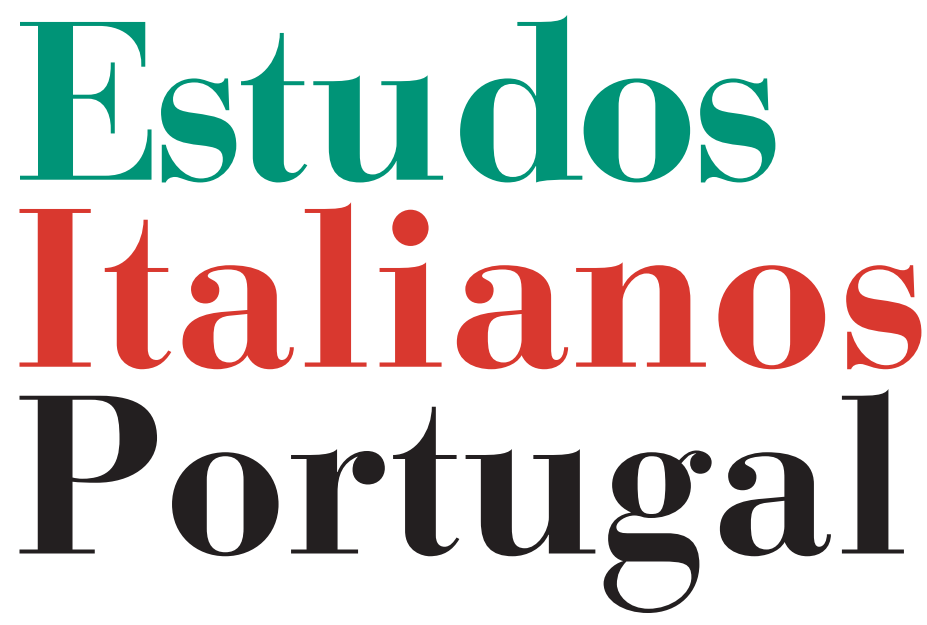

Instituto

Italiano

de Cultura

de Lisboa

Nova Série

$\mathrm{N}^{\mathbf{0}} \mathbf{0}$ 
PRESENÇA ITALIANA NA TRATADÍSTICA

PORTUGUESA DA PRIMEIRA METADE

DO SÉCULO XVIII.
A NOVA ARTE DE CONCEITOS
DE FRANCISCO LEITÃO FERREIRA*

\section{DAvide CONRIERI}

I. Nos textos portugueses de preceituação retórica e literária, da primeira metade do século XVIII, a presença italiana, declarada ou não que o seja, é relevante, manifestando-se quer através de afirmações e modalidades argumentativas de ordem teórica, quer através do recurso a passos utilizados na exemplificação. Essa presença tem vindo a atrair a atenção de lusitanistas italianos e portugueses, como Giuseppe Carlo Rossi, que no volume, La letteratura italiana e le letterature di lingua portoghese (Torino, SEI, s. d.; trad. port. de Giuseppe Mea, Porto, Telos, 1973), assinalou alguns casos, e Aníbal Pinto de Castro, que, em Retórica e teorização literária em Portugal do Humanismo ao Neoclassicismo (Coimbra, Centro de Estudos Românicos, 1973), dela elaborou um vasto levantamento. Não parece ter atraído, porém, a atenção dos italianistas. E, contudo, na perspectiva do especialista em história da literatura italiana, aquela presença merece, da mesma feita, todo o interesse, tendo em vista não só a história da fortuna e da recepção da literatura italiana, enquanto testemunho do conhecimento e do apreço merecidos pelos seus textos e

* Traduzido por Rita Marnoto e Sónia Ferreira, do original, "Presenze italiane nella trattatistica portoghese della prima metà del Settecento. Il caso della Nova arte de conceitos di Francisco Leitão Ferreira", in Le varie fila. Studi di letteratura italiana in onore di Emilio Bigi, a cura di Fabio Danelon, Hermann Grosser, Cristina Zampese, Milano, Principato, 1997, pp. 150-164. 
pelos seus autores fora de Itália, como também, numa perspectiva especificamente orientada no sentido de avaliar a vitalidade e a ressonância, na Europa, da cultura literária de finais do século XVII e da sucessiva centúria, enquanto documento da eficácia das posições doutrinárias e das orientações interpretativas de teóricos e críticos italianos.

Sob esta óptica, a área portuguesa constitui um campo de observação privilegiado, uma vez que do seu seio brota, na primeira metade do século XVIII, a tentativa de criar uma tratadística retórica e literária em língua nacional, dotada de plena e proclamada consciência da novidade de um tal empenho. Francisco Leitão Ferreira, ao iniciar a Nova arte de conceitos (1718-1721), declara-se benemérito da Pátria, oferecendo-lhe, na sua língua materna, uma arte como aquelas que já haviam enriquecido as línguas grega, latina, italiana, francesa e espanhola. Por sua vez, D. Rafael Bluteau, censor da segunda parte da obra, tem o cuidado de confirmar que o seu autor é, efectivamente, o primeiro a dar lições, em língua portuguesa, acerca da boa eloquência. Luís António Verney, no Verdadeiro método de estudar (1746), na abertura da primeira das duas cartas dedicadas à retórica, observa que não existe nada mais útil do que uma tal disciplina, apesar de não haver outra que, em Portugal, seja tratada com tanto desleixo, indicando como principal e grande erro o facto de ser ensinada em latim. No começo da carta consagrada à poesia, lamenta que ainda ninguém se tenha dedicado à feitura de uma boa arte poética portuguesa, atribuindo a essa lacuna os defeitos dos poetas portugueses. Francisco José Freire, na dedicatória da sua Arte poética (1748), logo observa que a juventude portuguesa, em matéria tão vasta e dificil como o é a arte poética, não tem nenhum livro na sua própria língua que lhe possa facultar a mínima instrução, começando o Prólogo ao leitor com o anúncio, feito em tom triunfal, de que será finalmente publicada uma Arte poética "escrita no nosso idioma”. É apoiado, no louvor, pelos censores da obra, 
Ignácio de Carvalho e Sousa e José Barbosa, solícitos, um, em declará-la a primeira arte poética que se imprimia em português, o outro, em exaltar o autor como o primeiro, em Portugal, a descobrir a verdadeira fonte da poesia e a ensinar os seus segredos. Aliás, fora o próprio Francisco José Freire quem formulara, alguns anos antes, idêntico louvor, a propósito do seu manual de epistolografia, o Secretário português compendiosamente instruído no modo de escrever cartas (1745), afirmando que a obra seria a primeira, daquele género, que em Portugal se lia. ${ }^{1}$

No clima que imbuía a férvida actividade de uma tão vária teorização e preceituação, os tratadistas portugueses observavam atentamente o panorama europeu, para dele colherem sugestões, principalmente, e para além do que diz respeito à cultura espanhola - numa relação tão óbvia quanto difícil -, no que toca à cultura francesa e à italiana. A atenção dispensada a esta última encontra-se ligada, por elos de íntima coerência, com um interesse que é uma constante da cultura portuguesa, mas que, no século XVIII, era reavivado, além do mais, pelo extraordinário sucesso do teatro italiano em Portugal e pela estreita ligação à Academia da Arcádia. ${ }^{2}$ Valerá a pena recordar, a este propósito, mais do que a protecção dada pelo rei D. João V à Arcádia Romana (entre

1 Cf., por ordem, F. Leitão Ferreira, Nova arte de conceitos, primeira parte, Lisboa Ocidental, na oficina de António Pedroso Galrão, à custa de Miguel Rodrigues, 1718, p. 9; segunda parte, Lisboa, António Pedroso Galrão, 1721, p. s. n. [mas XXIV]; L. A. Verney, Verdadeiro método de estudar (cartas sobre retórica e poética), introdução e notas de Maria Lucília Gonçalves Pires, Lisboa, Presença, 1991, pp. 44 e 125-126; F. J. Freire, Arte poética, Lisboa, na oficina de Francesco Luís Ameno, 1748, pp. s. n. [mas III, XXIII, XXXIII, XXXVII, XLII]; Andrée Rocha, A epistolografia em Portugal, Porto, Imprensa Nacional-Casa da Moeda, 1985 , p. 32.

2 Cf., também para posteriores indicações bibliográficas, além do citado volume de G. C. Rossi, pp. 63-90 do original italiano, José da Costa Miranda, Estudos luso-italianos. Poesia épico-cavaleiresca e teatro setecentista, Lisboa, Ministério da Educação, Instituto de Cultura e Língua Portuguesa, 1990, pp. 193-357. 


\section{Davide Conrieri}

outras coisas, com a doação, em 1725, do palácio que iria servir de sede à Academia), o facto de nela se terem inscrito dois dos tratadistas supracitados - Leitão Ferreira, em 1720, com o nome de Tagídeo, e Verney, em 1743, com o nome de Verénio Origiano - e de o terceiro, Freire, conhecido, enquanto árcade, como Cândido Lusitano, ter tido um papel importantíssimo na Arcádia Lusitana, que se inspirava na romana.

Naturalmente que cada um dos tratadistas portugueses assumia posições muito próprias perante a cultura italiana, aceitando alguns dos seus contributos e ignorando ou refutando explicitamente outros. Pretendo começar o exame dessas posições detendo-me, neste ensaio, sobre alguns aspectos doutrinários da Nova arte de conceitos, em cujas páginas Leitão Ferreira recolheu as lições por ele próprio ministradas, ao longo de seis anos, na Academia dos Anónimos de Lisboa. ${ }^{3}$

II. Leitão Ferreira, na lição inaugural, expõe desta forma o seu horizonte de referências teóricas:

Seguirei as doutrinas do Conde Grão Cruz Manuel Tesauro, estabelecidas sobre os preceitos e textos de Aristóteles, não desprezarei as ponderações de Gracián, de Juglaris e Masénio, consultarei as crises francesas de Bouhours, Boileau e Rapino,

3 Sobre Academia dos Anónimos, cf. João Palma Ferreira, Academias literárias dos séculos XVII e XVIII, Lisboa, Biblioteca Nacional, 1982, pp. 71-74. Segundo resulta de dois passos da segunda parte da Nova arte de conceitos (pp. 147 e 197), Leitão Ferreira pensava publicar uma terceira parte da obra, consagrada a uma ampla dissertação sobre o equívoco. A numeração das lições, nas duas partes editadas da Nova arte de conceitos, é contínua (a primeira parte inclui as lições I-XII e a segunda as lições XIII-XXX). Descontínua é, contudo, a numeração das páginas. Para citações e remissões, indicarei directamente, no corpo do trabalho, a parte e as páginas referidas, em numeração romana e árabe. Nas citações da Nova arte de conceitos (em abreviatura N.A.), tal como nas da Arte poética de F. J. Freire, seguirei um critério de comedida actualização gráfica. As impressões de referência das duas obras são as indicadas na nota 1 . 
verei as sábias Observações de Muratori, Pallavicino e Garofalo, sem me esquecer dos ditames de Longino, das elegâncias de Demétrio, das ideias de Hermógenes, dos preceitos de Cícero e Instituições de Quintiliano (I, 8-9).

Solidamente enfileirados, como pano de fundo, em série, imprescindíveis tratadistas antigos ("sem me esquecer dos ditames de Longino, das elegâncias de Demétrio, das ideias de Hermógenes, dos preceitos de Cícero e Instituições de Quintiliano”). Na zona intermédia, não casualmente reunidos em grupos de três, os tratadistas seiscentistas do conceptismo e os seus críticos ("não desprezarei as ponderações de Gracián, de Juglaris e Masénio, consultarei as crises francesas de Bouhours, Boileau, e Rapino, verei as sábias Observações de Muratori, Pallavicino e Garofalo"). Em primeiro plano, isolado, Tesauro, e, enquanto sua base, destacado dos outros tratadistas antigos, Aristóteles ("Seguirei as doutrinas do Conde Grão Cruz Manuel Tesauro, estabelecidas sobre os preceitos e textos de Aristóteles"). Desenha-se, assim, o mapa de uma formação que assenta na retórica e na poética clássicas, que está especialmente atenta à tratadística seiscentista, e que se encontra informada acerca dos mais recentes debates europeus sobre a matéria.

Entre os tratadistas modernos recordados, os italianos, por si só, igualam em número o conjunto dos que representam outras nações: cinco, contra o espanhol Gracián, o alemão Masen, Masénio, e os três franceses. Bem mais numerosos são os literatos italianos citados como tratadistas ao longo da Nova arte de conceitos. Quanto ao Renascimento, o percurso estende-se entre citações esporádicas de Aldo Manuzio, Bartolomeo Cavalcanti, Iacopo Mazzoni, Orazio Toscanella, Gian Giorgio Trissino, Marco Girolamo Vida, Giovanni Antonio Viperano, Francesco Panigarola e outros, até às mais frequentes referências a Ludovico Castelvetro, Marcantonio Maioragio e, sobretudo, Giulio Cesare Scaligero. Do 


\section{Davide Conrieri}

século XVII, são reiteradamente citados os Proginnasmi poetici de Benedetto Fioretti. A essa obra recorre, quase sempre, Leitão Ferreira, em virtude do seu aspecto de depósito de passos de autores antigos, dela retirando, por exemplo, uma frase do sofista Libânio (II, 130), uma do sofista Dionísio (II, 171), ou uma de Demétrio (II, 394). Aos escritores renascentistas, recorre prevalentemente por via da sua actividade de tradutores ou comentadores de tratadistas gregos e latinos. A função subsidiária, relativamente à tradição clássica, que, para Leitão Ferreira, desempenham esses literatos italianos, explica que não lhes seja feita alusão, no excerto supracitado. Naquele preciso momento, importava, tão só, nomear pontos de referência fundamentais, ou que qualificassem a orientação escolhida pelo autor, e esboçar um modo de ordenação.

Dos tratadistas nomeados naquele excerto, dois têm, na obra de Leitão Ferreira, uma importância, de facto, marginal. Luigi Giuglaris é explicitamente referido numa única ocasião ao longo da Nova arte de conceitos (I, 196-197) e o facto de ser mencionado no excerto proemial justifica-se, como sugere Pinto de Castro, ${ }^{4}$ pela difusão, nas escolas jesuítas, do seu compêndio de retórica, Ariadne rhetorum (1651), que continuava a ser reimpresso, em Évora, no ano de 1714. Biagio Garofalo nunca chega sequer a ser explicitamente referido ao longo da obra. No excerto proemial, é claramente recordado pelo Ragionamento, com o qual interviera na polémica Orsi-Bouhours. Se se quisesse tentar explicar - para além da vaga indicação de Pinto de Castro $^{5}$ (o texto de Garofalo é um dos mais importantes da polémica) - a razão pela qual, de entre os participantes na polémica, Leitão Ferreira teria decidido referir, exactamente, Garofalo, poder-se-ia avançar a hipótese de que, com a referência ao Ragiona-

${ }^{4}$ Cf. Retórica e teorização literária, p. 165 e também p. 83, nota 1.

5 Cf. Retórica e teorização literária, p. 168. 
mento, pela primeira vez impresso em $1708,{ }^{6}$ quisesse parecer actualizado relativamente aos últimos desenvolvimentos italianos do debate suscitado pela crítica francesa, à qual tinha acabado de se referir. Deste modo, poder-se-ia observar que quase todos os temas tratados no Ragionamento podiam despertar o seu especial interesse e que as posições acerca deles assumidas por Garofalo talvez sejam tacitamente tidas em consideração na Nova arte de conceitos. É esse o caso do carácter da ligação entre som e ideia na palavra, convencional para Garofalo, necessário para Leitão Ferreira; da origem passional da hipérbole, relativamente à qual se regista uma ampla consonância entre ambos; do significado alegórico das fábulas antigas, negado por Garofalo e reconhecido por Leitão Ferreira; da inspiração divina dos poetas, "uma impostura", para Garofalo, mas não para Leitão Ferreira. ${ }^{7}$

Como mostrou Pinto de Castro $^{8}$, e conforme explicarei melhor adiante, na Nova arte de conceitos, outra é a importância, que não a de Giuglaris e Garofalo, dos restantes tratadistas italianos nomeados no citado excerto da lição inaugural. Quanto a Muratori, torna-se evidente que Leitão Ferreira efectuou uma leitura atenta e inteligente do tratado Della perfetta poesia italiana spiegata e dimostrata com varie osservazioni. É precisamente à luz de uma tal leitura que deve ser considerada a sua proclaração de fidelidade às doutrinas de Tesauro.

José Freire, ao falar, na sua Arte poética, da metáfora, e depois de sobre ela fazer algumas observações, remete os

${ }^{6}$ Ragionamento di Biagio Garofalo in difesa delle Considerazioni sopra il libro Della maniera di ben pensare [...], Roma, Francesco Gonzaga, 1708; II ed. aumentata, Roma, Francesco Gonzaga, 1709; depois na edição de Soliani, em Modena, 1735, das Considerazioni de Giovan-Gioseffo Orsi, vol.II, pp.117-156.

7 Cf., por ordem, o Ragionamento na edição de Modena, pp.146; 148-150; 150-151; 151, com N.A., I, 108-116; II, 72 e 265; I, 47-48 e 54-56; I, $130-132$.

${ }^{8}$ Cf. Retórica e teorização literária, pp.157-163 e 169-176. 
leitores desejosos de um mais vasto desenvolvimento do assunto para os mestres que o trataram exaustivamente, acrescentando:

Unicamente nos parece necessário dizer aqui alguma cousa aos principiantes, a respeito das comparações e das metáforas. A respeito destas dizemos que deve haver grande cautela nas regras e exemplos que sobre elas dá o Conde Manuel Tesauro no seu Cannocchiale aristotelico, porque talvez foi o que tratou peior deste assunto, sendo o que dele escreveu com mais extensão (121-122).

Depois de ter citado várias metáforas reprováveis de Tesauro, sobre ele tece o seguinte juízo global:

Este autor era homem de grande doutrina e de um engenho vivo, ainda que daqueles a que os Franceses chamam "brilhantes", porém a destemperada ambição de novidade lho depravou. Por isso quis enganar o mundo com o nome de Aristóteles, e o encheu de conceitinhos e de argúcias frívolas, ridículas, pueris, insulsas e irreverentes, como são as metáforas apontadas, o que tudo diz o insigne Salvini nas Notas a Muratori tomo I, pag. 249. Muito ajudou a Tesauro em estabelecer o péssimo gosto Lourenço Gracián na sua Arte y agudeza de ingenio, infestando ainda mais a Espanha, como o outro a Itália, e ambos o mundo (122).

O juízo remete para a Perfetta poesia de Muratori e, mais precisamente, para esta nota de Anton Maria Salvini:

Ove si parla delle metafore del Tesauro, sarebbe stato bene per util pubblico aggravare la mano sopra quel libro, che inganna il mondo sotto nome d'Aristotele, e ha riempiuto l'Italia di concettini; ed egli è pieno d'arguzie frivole, buffonesche, puerili, insulse, irriverenti. Quella metafora di proporzione 
benissimo considerata da Aristotile, a quante mai sciocchezze gli aprì la strada? Pure vi ha del buon in quel libro; come l'Indice Categorico, il riconoscere le misure e le corrispondenze nelle parti del periodo. E egli era uomo di dottrina, e d'ingegno vivo e brillante; ma per istemperata ambizione di novità si stravolse ("Quando se fala das metáforas de Tesauro, teria sido conveniente, para utilidade do público, fazer pesar a mão sobre aquele livro, que engana o mundo com o nome de Aristóteles, e que encheu a Itália de conceitinhos e está repleto de argúcias frívolas, ridículas, pueris, insulsas, irreverentes. Aquela metáfora de proporção, tão bem considerada por Aristóteles, a quantas tolices lhe abriu caminho? Também há coisas boas naquele livro, como o Índice Categórico, o reconhecimento das medidas e das correspondências nas partes do período. Era um homem de doutrina e de engenho vivo e brilhante, porém, por destemperada ambição de novidade, desvirtuou-se").

O parecer de Freire decalca, em boa parte, a nota de Salvini. Mas, na verdade, não era necessária aquela nota - que, como todas as outras de Salvini, acompanha o tratado muratoriano a partir da impressão de 1724 -, para alimentar num leitor, afinado pelo tom da Perfetta poesia, mais do que a desconfiança, o repúdio de Tesauro. Bastavam, para tanto, os juízos de valor sobre ele expressos por Muratori.

A citada advertência de Freire acerca da cautela com que os principiantes devem olhar para o Cannocchiale aristotelico,

9 Cito da impressão de Coleti, 1724, do tratado de Muratori, Della perfetta poesia italiana spiegata, e dimostrata com varie osservazioni, tomo I, p. 249 , que era a impressão que Freire manejava. Advirto que, por regra, me referirei à Perfetta poesia (em abreviatura P.P.), indicando directamente no texto a página da edição moderna, preparada por Ada Ruschioni, em dois volumes (mas com numeração de páginas contínua), Milano, Marzorati, 1971, a qual não reporta as anotações de Anton Maria Salvini. Ao citar a edição de Ruschioni, modernizarei comedidamente, da mesma forma, grafia e pontuação. 
ou melhor, se devem manter bem longe dele, com a explicação que lhe é correlata, repete Muratori:

Solamente reputo necessario far avvisati i giovani che in ciò molto non si fidino alla scorta, agl'insegnamenti ed esempi del Tesauro, il quale forse più di tutti copiosamente, ma senza fallo men bene di tutti, ha ragionato delle metafore nel suo Cannocchiale aristotelico, almen per quello che riguarda gli esempi (299: "Somente considero necessário advertir os jovens de que não confiem muito nos ensinamentos e exemplos de Tesauro, o qual, talvez mais que todos copiosamente, mas sem dúvida menos bem que todos os outros, reflectiu acerca das metáforas no seu Cannocchiale aristotelico, pelo menos no que diz respeito aos exemplos").

De seguida, Muratori volta a tecer uma opinião geral sobre Tesauro, associando-o a Gracián, entre os maiores responsáveis pela "peste literária" representada pelo estilo conceptista, num excerto do qual deriva, provavelmente, a última frase do citado passo de Freire:

Poca obbligazione in verità ha la Spagna a Baldassar Graziano, che nel suo Trattato delle Acutezze ha posto in sì gran riputazione questo meschinissimo stile. Pochissima ancor noi ne abbiamo ad Emanuel Tesauro, che n'abbia co' suoi libri, e sopra tutto col Cannocchiale aristotelico autenticato l'uso. Questi autori, ingegni per altro felicissimi, hanno oltra il dovere guasta e corrotta la natura della vera eloquenza, e della buona poesia, quando più si vantavano d'averla aiutata. Né per mio consiglio si dovrebbe permettere a' giovani la lettura di sì fatti maestri [...] (330: "Poucas obrigações, na verdade, tem a Espanha para com Baltasar Gracián, que no seu Tratado das Agudezas conferiu tão grande reputação a este estilo extremamente mesquinho. Pouquíssimas também temos nós para com Emanuele Tesauro, que com os seus livros e, sobretudo, com o Cannocchiale aristotelico, autori- 
zou o seu uso. Estes autores, engenhos, aliás, felicíssimos, danificaram, para além do devido, e corromperam a natureza da verdadeira eloquência e da boa poesia, mesmo quando mais se vangloriavam de a terem ajudado. Nem, segundo o meu juízo, se deveria permitir aos jovens a leitura de tais mestres [...]”).

Poucas páginas volvidas, Muratori designa Tesauro, peremptoriamente, como um "infelice maestro e sponitore de' precetti aristotelici" (333: "infeliz mestre e intérprete dos preceitos aristotélicos"). Doutras vezes, Tesauro aparece na Perfetta poesia ou como professor na "scuola del pessimo gusto e delle bagatelle" (492: "escola do péssimo gosto e das bagatelas"), ou como autor de conceitos que, "posti alla coppella" (321: "copelados”), para usar uma expressão de Muratori, acabam por se mostrar falsos, pueris, ridículos, ou, na melhor das hipóteses, de mau gosto, destemperados, inconvenientes, inoportunos (cf. 299, 331-333, 336, 470, 490). Salvini, portanto, bem podia exprimir o desejo de que o juízo acerca de Tesauro, no tratado de Muratori, soasse ainda mais grave. Mas mesmo o modo como esse juízo soava não deixava lugar a dúvidas: Tesauro devia ser evitado quer como teórico, porquanto corruptor do bom gosto e intérprete arbitrário de Aristóteles, quer como modelo de uma escrita metafórica, porquanto propenso a subtilezas ocas.

Perante esta indicação, plenamente acolhida por Freire na sua Arte poética, em consonância com a Perfetta poesia, de tal forma que aquela mostra ser, tantas vezes, uma tradução ou pouco mais, desta, ${ }^{10}$ sobressai o implícito significado polémico da afirmação de Leitão Ferreira, "Seguirei as doutrinas do Conde Grão Cruz Manuel Tesauro, estabelecidas sobre os preceitos e textos de Aristóteles". Na qual pesa, certamente, e antes de mais, a eleição de Tesauro como

${ }^{10}$ Cf. Álvaro Júlio da Costa Pimpão, "Um plágio de Francisco Joseph Freire (Cândido Lusitano)”, in Biblos, 23, 1, 1947, pp. 203-209. 
guia, mas também o reconhecimento da legitimidade da ligação entre as suas doutrinas e os preceitos e os textos aristotélicos. O preciso oposto do Tesauro de Muratori, "infelice maestro e sponitore de' precetti aristotelici". De resto, para Leitão Ferreira, o teórico italiano, sempre referenciado com respeito e muito frequentemente com admiração, é o "agudíssimo Tesauro", o "doutíssimo Tesauro", o "sutil Tesauro" (II, s. n., mas XI, 105 e 229).

A escolha de seguir a doutrina de Tesauro não é "ingénua”, pela parte de Leitão Ferreira, mas reconhecidamente polémica. Pressupõe não só os reparos que aquela doutrina teria merecido, talvez de modo genérico e indirecto, das "crises francesas de Bouhours, Boileau e Rapino" ou das tomadas de posição de Pallavicino e Garofalo, como também os ataques de Muratori que visavam pessoalmente Tesauro. Vale a pena insistir sobre o carácter peculiar da ligação entre Il cannocchiale aristotelico e a Nova arte de conceitos, mais do que quanto o fez Pinto de Castro, apesar de ter escrito e mostrado, através de comparações textuais precisas, como o contributo da primeira obra para a segunda "sobreleve, no alcance e na extensão, todos os outros, e se apresente de forma muito vária". ${ }^{11}$ Quanto à obra de Leitão Ferreira, a superioridade de Tesauro em relação aos outros tratadistas não é meramente quantitativa, mas hierárquica. Il cannocchiale aristotelico não é só o texto que, mais do que qualquer outro, influencia a Nova arte de conceitos, mas é o texto que lhe serve de exemplo, ao passo que os restantes textos que a plasmam têm o valor de fontes complementares. A natureza da ligação entre Il cannocchiale aristotelico e a Nova arte de conceitos já tinha sido apreendida por Rafael Bluteau, quando, na nota censória à segunda parte do tratado de Leitão Ferreira, depois de ter declarado Tesauro "o primeiro ou certamente o mais metó-

11 Retórica e teorização literária, p. 158; para a respectiva demonstração, cf. pp. $158-163$. 
dico mestre e mais autorizado legislador da aguda e arguta locução", escrevia, "à imitação ou com emulação deste discretíssimo autor italiano, o primeiro que em língua portuguesa deu lições desta aguda eloquência é o beneficiado Francisco Leitão Ferreira". A Nova arte de conceitos pode ser considerada o equivalente português do Cannocchiale aristotelico, ao qual a liga uma relação imitativa e emulativa.

III. Em âmbito doutrinal, a dependência de Leitão Ferreira relativamente a Tesauro é muito ampla e envolve pontos capitais. Nomeado ou não, traduzido palavra por palavra ou resumido, Il cannocchiale aristotelico dita fundamentos e desenvolvimentos do sistema retórico exposto na Nova arte de conceitos. Ilustrou-o, apresentando significativos exemplos, Aníbal Pinto de Castro, para o qual remeto. Permanecendo, todavia, no âmbito doutrinal, podem-se observar diferenças, a vários níveis, entre os dois tratados. Pinto de Castro chamou a atenção para a "frontal discordância" em torno da natureza das formas patéticas. ${ }^{12}$ Sobre essa discordância, manifestada por Leitão Ferreira, deter-me-ei também eu, com o intuito de acrescentar algumas considerações às desse crítico.

Mas antes disso, é meu desejo indagar uma outra discordância, a qual, de facto, não tendo sido declarada por Leitão Ferreira, pode passar despercebida, mas que, contudo, é digna de observação, para além de um interesse estritamente técnico-retórico, em virtude daquilo que revela acerca da atitude global do autor da Nova arte de conceitos. A discordância ocorre entre o tratamento, nesta obra, das causas das metáforas, e o tratamento, no Cannocchiale aristotelico, das causas das argúcias. Leitão Ferreira atribui às metáforas seis classes de causas: causa eficiente, instrumental, material, formal, final e exemplar. Tesauro atribui às argúcias cinco classes de causas, as mesmas

12 Retórica e teorização literária, pp. 163 e 213-215. 
que acabámos de enumerar, excluindo a causa exemplar. Leitão Ferreira dedica à causa eficiente um espaço incomparavelmente maior do que dedica ao conjunto de todas as outras causas. Mas reduz a multiplicidade das causas eficientes das argúcias já enumeradas no título e depois examinadas ao longo do capítulo III do Cannocchiale aristotelico, ${ }^{13}$ ou seja, "Iddio, Spiriti, Natura, Animali e Uomini" ("Deus, Espíritos, Natureza, Animais e Homens"), apenas à última. A diferença é tão evidente, quanto facilmente explicável. Leitão Ferreira centra o próprio tratado sobre as argúcias verbais produzidas pelos homens. Mas a explicação abre caminho a outras perguntas, que ganham todo o sentido a partir do momento em que Leitão Ferreira considera o tratado de Tesauro não como referência de que se sirva esporadicamente, mas como texto que, no seu conjunto, orienta toda a sua preceituação. Adquire, então, um sentido muito preciso, interrogarmo-nos acerca daquilo que, no Cannocchiale aristotelico, Leitão Ferreira remete para uma zona de sombra ou deixa mesmo cair, acerca das razões por que o faz e dos efeitos que tem em vista.

Para definir a metáfora "em toda a sua extensão", Leitão Ferreira retoma a definição de Tesauro, que lhe parece dever ser venerada e seguida, porquanto a mais conforme com os seus fundamentos ("a qual veneramos e seguimos, como a mais conforme aos nossos fundamentos"), traduzindo à letra, quando escreve, "Palavra peregrina, que velozmente significa e demonstra um objecto por meio de outro" (I, 247; cf. C. A., 302). Mas sabe certamente que, também em contradição com aquela sua definição restritiva, Tesauro não vê a metáfora verbal produzida pelo homem como mais do que um tipo de sinal metafórico, num mundo repleto de

13 Do tratado tesauriano (em abreviatura, C. A.) sigo a edição definitiva, Torino, Zavatta, 1670, reimpressa anastaticamente sob a direcção de August Buck, Berlim, Zurique, Gehlen, 1968. Refere-se-lhe a indicação das páginas fornecida no texto. 
sinais metafóricos, cujo aspecto é vário e cuja origem é muito diversificada. Naquele mundo, a quase inexaurível prole da argúcia possui duas dimensões: uma dimensão horizontal, que diz respeito à riquíssima tipologia segundo a qual se configura o sinal metafórico verbal ou não verbal (basta recordar que geralmente "le immagini sono metafore" C. A., 12: “as imagens são metáforas"); e uma dimensão vertical, que diz respeito à proveniência do sinal metafórico, dimensão no topo da qual está mesmo "il grande Iddio [che] godè talora di fare il poeta e l'arguto favellatore" (C. A., 59: “o grande Deus [que] se deleitou por vezes a fazer de poeta e de arguto falador").

Da primeira dimensão, permanecem, na Nova arte de conceitos, algumas marcas, designadamente na lição inaugural, quando é tratado o conceito transeunte, ou seja, o conceito mental enquanto comunicado através de palavras, sinais e obras. De forma simplificada e abreviada, é reproduzido o quadro das origens da argúcia do capítulo I do Cannocchiale aristotelico, observando-se explicitamente, e em particular, que símbolos, hieroglifos e emblemas "são engenhosos, porque alusivos, e figurados, porque metafóricos" (I, 31), e que acenos, gestos e movimentos do corpo podem ter um carácter metafórico (I, 27, onde é reproduzida, a partir do cap. II do C. $A .$, p. 24 , não só esta afirmação, mas também o excerto que começa por "Falam os olhos com os olhos [...]"). Da segunda dimensão, nada consta na Nova arte de conceitos. A densidade metafísica - mesmo sendo especiosa - que, no Cannocchiale aristotelico, caracterizava a argúcia, por ser apresentada como modalidade expressiva não apenas do homem, mas também da Natureza, das criaturas angélicas e demoníacas, e do próprio Criador, é eliminada. Através da combinação daquelas duas dimensões na sua plenitude, o mundo de Tesauro vibrava, num pulular de sinais argutos, com uma espécie de embriaguez metafórica. Ao reduzir drasticamente a dimensão horizontal da argúcia e suprimir a vertical, Leitão 
Ferreira atenua, a ponto de quase o extinguir, o que de tão vertiginoso há no horizonte metafórico de Tesauro, ao mesmo tempo que tende a restringir o teatro da metáfora, do universo à academia.

Fala por si só, nesse sentido, a aproximação entre o início do Cannocchiale aristotelico e o início da Nova arte de conceitos. O começo do Cannocchiale aristotelico representa, logo desde a primeira tirada, um palco grandioso e solene, que evoca, para celebrar o "divin parto dell'ingegno" ("o divino parto do engenho"), e o "pellegrino miracolo" ("peregrino milagre") que é a argúcia, todos os séculos e todos os homens: "Un divin parto dell'ingegno, più conosciuto per sembianti che per natali, fu in ogni secolo e apresso tutti gli uomini in tanta ammirazione che, quando si legge e ode, come un pellegrino miracolo, da quegli stessi che nol conoscono, con somma festa e applauso è ricevuto" (1: "Um divino parto do engenho, mais conhecido pelas feições do que pela origem, mereceu, em todos os séculos e para todos os homens, tanta admiração que, quando se lê ou se ouve, como um peregrino milagre, mesmo por aqueles que não o conhecem, com absoluta festa e aplauso é recebido"). Por sua vez, o início da Nova arte de conceitos é dedicado ao louvor das práticas da academia, reconhecendo nelas aquela "conversação de exemplares e eruditas pessoas" (I, 12) que constitui "o mais útil e honesto passatempo do mundo" (I,1), e convertendo-a em palco "onde se disputam, decidem e aprendem as agudezas do discurso humano" (I, 7).

Restringida a causa eficiente das metáforas à obra humana, Leitão Ferreira retoma a sua divisão em três formas operativas principais - engenho, furor, exercício -, bem como as suas ulteriores subdivisões, do Cannocchiale aristotelico, que, neste domínio, segue com extrema fidelidade. Interessa notar que à quinta e última modalidade de exercício, a imitação, concede muito espaço, dedicando-lhe a sétima e a oitava lições. Encara o problema tradicional da unidade ou multiplicidade 
dos modelos, relembrando, além do mais, as polémicas entre Poliziano e Cortesi e entre Bembo e Pico della Mirandola. Todavia, indaga sobretudo o problema, caracteristicamente seiscentista, da distinção entre furto, imitação e emulação, chegando a soluções de certo mérito, assunto cujo desenvolvimento transcende o alcance do presente trabalho. De momento, bastará sublinhar como se encontra profundamente envolvido no problema, tanto mais que, não satisfeito, a esse propósito, com as considerações de Tesauro, as completa com as de Sforza Pallavicino. E é ao retomar aquelas considerações, acerca de um problema tão caracteristicamente barroco, que Leitão Ferreira contrai a sua maior dívida para com o Trattato dello stile e del dialogo, que, noutra ocasião, mostra conhecer bem. Com o grande interesse que dedica à questão da imitação, deve-se relacionar o alargamento do elenco de Tesauro, pelo que diz respeito às causas da argúcia, com uma sexta causa, a exemplar, que é a imitação que o artífice faz ou de si mesmo, enquanto inventor, ou de outrem.

Bastante significativas são também as alterações, quanto à doutrina de Tesauro, que Leitão Ferreira introduz nas outras causas, com excepção da formal, reconduzida, como em C.A., 234, à significação engenhosa. A causa instrumental, que, para Tesauro, consiste nas diversas configurações da argúcia (arquetípica, vocal, escrita, dos gestos, dos corpos figurados e composta, C.A., cap. II), para Leitão Ferreira é "o entendimento" (I, 207), ou seja, o intelecto. A causa material, que para Tesauro é a mesma da retórica, isto é, a "matéria civil" (C.A., 545), para Leitão Ferreira é "o vocábulo translato enquanto conserva a sua significação própria" (I, 208). A causa final, que para Tesauro (C.A., 541) é a persuasão nos três géneros retóricos - demonstrativo, deliberativo e de juízo -, é para Leitão Ferreira "a novidade engenhosa [da metáfora] que nos ânimos move admiração e deleite, pela inopinada proporção dos correlatos, descobrindo algum predicado genérico em que convenham" (I, 208-209). 
Todas essas alterações convergem no sentido de fechar o círculo da operação metafórica num espaço autónomo, intelectualista e linguístico. Qualquer reenvio para um espaço externo, que de facto persiste, de forma apenas superficial que seja, em Tesauro (a matéria civil, os fins gerais da retórica), é suprimido.

Mantém perfeita coerência com essas alterações, a importante correcção à doutrina de Tesauro relativamente às figuras patéticas, a que já se fez referência. Tesauro distingue três classes de figuras retóricas-harmónicas, patéticas e engenhosas. Leitão Ferreira utiliza uma longa argumentação, que se estende da lição XVII à XVIII, para demonstrar que as figuras patéticas devem ser consideradas figuras engenhosas, em virtude da própria definição que Tesauro dá de metáfora e de figuras patéticas. Corrige, portanto, Tesauro com Tesauro, inscrevendo, naquele círculo fechado de que falava, figuras que, para o autor do Cannocchiale aristotelico, ficavam de fora, sendo consideradas, sobretudo, em virtude da sua dependência dos "movimenti dell'anima" (C.A., 212: "movimentos da alma”). Se se acrescentar que Leitão Ferreira não tem em consideração as figuras harmónicas, bem se vê como ele pretenda garantir, mais do que a proeminência, a quase exclusividade dos procedimentos engenhosos no campo da retórica e da poética.

Poder-se-à, então, concluir, que a teoria da elocução arguta do Cannocchiale aristotelico aparece na Nova arte de conceitos, por um lado, empobrecida pela subtracção de aberturas e de ressonâncias - nada de metaforismo universal e metafísico -, mas, por outro lado, intensificada pela exaltação do seu aspecto intelectualista e linguístico e da sua importância no âmbito do discurso humano.

IV. E, em tudo isto, Muratori? Como é que aquele Muratori, tão severo para com Tesauro, não conseguiu orientar diversamente a visão de Leitão Ferreira? No entanto, Mura- 
tori ocupa, na Nova arte de conceitos, logo a seguir a Tesauro e de entre os tratadistas modernos, um lugar de primeiro plano. Pinto de Castro mostrou como as especulações de Muratori, acerca da relação entre intelecto e fantasia na produção de imagens, agradaram tanto a Leitão Ferreira que o levaram a fazê-las suas, tendo-as em boa parte traduzido, além do mais, na lição XIX. Seria mesmo possível registar um elenco significativo das dívidas contraídas, quase sempre tacitamente, pela Nova arte de conceitos, relativamente à Perfetta poesia. Desde a prudente referência, logo na lição III (I, 61), à noção de "verosímil fantástico", até à sua franca adopção, de seguida (cf., p. e., II, 127); desde o repetido recurso à conexão "bom gosto" (I, 168 e II, 193), à apropriação, extremamente fiel, da descrição dos "tre mondi, o regni della Natura" (P.P., 102: "três mundos, ou reinos da Natureza"; N.A., I, 269); desde o decalque da enumeração dos requisitos que devem concorrer nos correlatos metafóricos ("è d'uopo che oltre alla simiglianza della figura vi sia quella del ministerio e dell'azione", P.P., 102: "é necessário que, para além da semelhança da figura, exista a do ministério e da acção"; "semelhança na figura, semelhança na acção, e semelhança em o ministério", N.A., II, 293), à reafirmação da inadmissibilidade de metáforas recíprocas de uma metáfora admissível como aquela do rouxinol, 'organo piumato' (P.P., 296: ‘órgão plumado’; N.A.,II, 326-329). Não é oportuno, presentemente, continuar o elenco iniciado, que regista e continuaria a registar dívidas em pontos efectivamente relevantes, sob uma perspectiva doutrinal.

Bastará notar mais uma dívida que pode parecer deveras surpreendente. A definição do engenho, perno do plano teórico da tesauriana, Nova arte de conceitos, vai-a Leitão Ferreira buscar não ao Cannocchiale aristotelico (82, "l'ingegno naturale è una maravigliosa forza dell'intelletto, che comprende due naturali talenti, perspicacia e versatilità": "o engenho natural é uma maravilhosa força do intelecto, que com- 
preende dois talentos naturais, perspicácia e versatilidade"), mas à Perfetta poesia:

L'ingegno secondo la mia sentenza altro non è se non quella virtù e forza attiva con cui l'intelletto raccoglie, unisce, e ritruova le simiglianze, le relazioni, e le ragioni delle cose (286: "O engenho, segundo a minha opinião, não é senão aquela virtude e força activa com que o intelecto recolhe, une, e acha as semelhanças, as relações e as razões das coisas”).

amplificando-a apenas ligeiramente, para depois a conduzir, na esteia do modelo de Tesauro, pela referência aos seus dois talentos naturais:

O engenho humano, que é uma natural virtude, prodigiosa presteza, e veemente força, com que o entendimento recolhe, une, separa, penetra, acha, e sutiliza as semelhanças, harmonias, noções, razões e relações das cousas, compreende em si outras duas virtudes, ou talentos naturais, que são perspicácia e destreza (I, 125-126).

Apesar do tipo de coincidências e de afinidades exemplificado, entre a Perfetta poesia e a Nova arte de conceitos, este último tratado consegue preservar o seu carácter tipicamente barroco por dois meios.

$\mathrm{O}$ primeiro consiste em caldear afirmações provenientes da Perfetta poesia com refutações não menos importantes. Assim, Leitão Ferreira aceita, conforme foi dito, as especulações de Muratori sobre a relação entre intelecto e fantasia na criação de imagens, bem como os respectivos critérios de avaliação da sua verosimilhança. De seguida, contudo, considera as metáforas, não como Muratori, produtos da fantasia, "immagini fantastiche" (P.P., 304: "imagens fantásticas"), mas antes, produtos do intelecto e do engenho: "a translação [...] é um movimento que não pára, porque é como uma roda, que tem por eixos o engenho e o discurso" (I, 123; 
para uma descrição concreta do espaço reservado à fantasia e ao engenho na formação das metáforas, compare-se P.P., 297-298, com N.A., 104).

Se se considera que a fantasia é tida, por Leitão Ferreira, como subordinada ao engenho (II, 135 e 141), poder-se-á avaliar toda a distância que este tratadista coloca entre si e Muratori num ponto capital, e compreender - mesmo sem uma demonstração analítica, que de momento não é possível apresentar - como, ao transferi-las para um contexto teórico diverso, torna débeis, nas suas consequências, aquelas especulações de Muratori que acolhia com pleno consenso.

O segundo meio consiste em interpretar, em direcção acentuadamente barroca, posições que são, afinal, de Muratori. É dificil imaginar um Muratori que, a quem quisesse compor conceitos paradoxais aconselhasse,

Para desempenhar este primor, valha-se das repugnâncias e sofismas, das exagerações e fingimentos, das proposições contraditórias, das dissonâncias das espécies, da permutação dos atributos, das ponderações quimerizadas, e de outras cores ou formas de dizer fora daquela comua opinião que os juízos humanos têm das cousas (II, 238).

Pouco muratoriano, na verdade, tendo em linha de conta os excessos de conteúdo e a ênfase de tom, é um excerto como este. Contudo, bem mais muratoriana é a conclusão que lhe dá Leitão Ferreira: "mas execute-o com tal prudência, moderação e economia, que não incorra em falsidade de conceito intrínseca e sustancial". Sobretudo, inegavelmente muratoriano é o princípio que, considerado na sua abstracção e generalidade, poderia autorizar, no plano teórico, o passo de Leitão Ferreira:

O sia dunque verisimile, o vero, o pure appaia falso, inverisimile, e impossibile ciò che la fantasia rappresenta, purché esso faccia 
colla sua significazione intendere un qualche vero all'intelletto, ragionevolmente piace all'anima nostra, perché questa materia avrà il fondamento del bello, cioè il vero (P.P., 142: "Ou seja, portanto, verosímil, ou verdadeiro, ou pareça até falso, inverosímil e impossível aquilo que a fantasia representa, ainda que faça com a sua significação entender uma qualquer verdade ao intelecto, razoavelmente agrada à nossa alma, porque essa matéria terá o fundamento do belo, ou seja, o verdadeiro").

Não só este passo da Perfetta poesia poderia ter invocado, como suporte do seu trecho, Leitão Ferreira, mas outros, ainda mais consistentes do que o citado, a começar pela fundamentada defesa do verdadeiro, "espresso con immagini false e mentitrici espressioni” (211: “expresso com imagens falsas e expressões mentirosas”), que ocupa a maior parte do capítulo XVI do livro I.

Análogas considerações se podem tecer relativamente à legitimação, por parte de Leitão Ferreira, de expressões, segundo ele próprio diz, inacreditáveis e inverosímeis (cf., p. e., II, 266, onde se dá aprovação a uma hipérbole "incrível e inverisímil"). Tais expressões são admitidas porquanto suposto fruto das paixões, por sua natureza produtoras de visões deformantes. Em consonância com a doutrina exposta na Perfetta poesia, em particular no capítulo XVIII do livro I, que afunda os seus sólidos princípios nas afirmações, "il fondamento che più spesso ha la fantasia di creder vere o verisimili le cose vien dagli affetti" (232: "o fundamento que mais frequentemente tem a fantasia para crer como verdadeiras ou verosímeis as coisas vem dos afectos"), e, "il poeta rappresentante se stesso, o altra persona agitata da qualche violenta passione, lodevolmente espone i deliri della sua fantasia" (237: "o poeta, ao representar-se a si próprio, ou a outra pessoa agitada por uma qualquer paixão violenta, de modo louvável expõe os delírios da sua fantasia”). É verdade, pois, que Muratori impõe como cautela um controlo 
do bom gosto e do juízo acerca da real conformidade das imagens patéticas sobre a condição da perturbação emotiva à qual se atribuem. Mas, é igualmente verdade, conforme observa Leitão Ferreira, que um controlo desse género deixa uma grande margem de subjectividade

porque uma reflexão ou imagem $v \cdot g$. fantástica ou intelectual, uns a terão por própria e verisímil da pessoa, e outros a condenarão por inverisímil e imprópria, e só o juízo de um leitor ou ouvinte perspicaz poderá ser o árbitro competente (II, 122).

Reunindo as linhas da argumentação de Leitão Ferreira, mostra-se clara uma importante consequência - talvez a mais importante $-\mathrm{da}$ tese segundo a qual o estilo das imagens patéticas é naturalmente engenhoso. Com essa tese, Leitão Ferreira alarga, de facto, os limites prescritos por Tesauro ao âmbito do engenho, mas, além disso, oferece à sua mais despreconceituada audácia de engenho uma justificação que leva em linha de conta o antitesauriano Muratori. Apenas será necessário que aquela audácia pareça produto da agitação do espírito e que lhe seja tida como conforme, por um "leitor ou ouvinte perspicaz".

Poder-se-á notar que Leitão Ferreira lê a Perfetta poesia sob uma óptica direccionada, abstraindo alguns preceitos do seu contexto e forçando a sua aplicação através dos juízos que elabora, preceitos que teóricos portugueses da geração posterior à sua, como Verney e Freire, farão mais fiéis às intenções do tratado de Muratori. Poder-se-á, ainda, notar, que o modo como Leitão Ferreira se serve da lição daquele tratado nos diz muito além disso, nos confirma também algo acerca da mentalidade e do gosto de Muratori. ${ }^{14}$ Reflectida

14 Digo que "nos confirma", pensando sobretudo no convincente ensaio de Fiorenzo Forti, "La poetica della meraviglia", no seu volume L. A. Muratori fra antichi e moderni, Bologna, Zuffi, 1953, pp. 189-225. Assinalo, pelo que diz 


\section{IO2 Davide Conrieri}

no espelho deformante, mas não falseador, da Nova arte de conceitos, a Perfetta poesia deixa transparecer, com singular relevo, quantas aberturas, quantos compromissos e quantas ambiguidades a ligam ao mundo assediado do Barroco.

respeito à definição e à função do engenho na Perfetta poesia italiana, o parágrafo, "Muratori: l'ingegno insufficiente", do trabalho, de grande importância para quanto ficou dito, e não só pelo teor da parte assinalada, de Elisabetta Graziosi, "Spirito, ingegno, intelletto ragione: nozioni a confronto in un dibattito del primo Settecento", in Ingenium propria hominis natura, Atti del Convegno Internazionale di Studi (Napoli, 22-24 maggio 1997), a cura di Stefano Gensini e Arturo Martone, Napoli, Liguori, 2002, pp. 327-360. 